\title{
Ideas and perspectives: climate-relevant marine biologically driven mechanisms in Earth system models
}

\author{
Inga Hense ${ }^{1}$, Irene Stemmler ${ }^{2}$, and Sebastian Sonntag ${ }^{2}$ \\ ${ }^{1}$ IHF, Center for Earth System Research and Sustainability, University of Hamburg, Hamburg, Germany \\ ${ }^{2}$ Max Planck Institute for Meteorology, Bundesstrasse 53, 20146 Hamburg, Germany \\ Correspondence to: Inga Hense (inga.hense@uni-hamburg.de)
}

Received: 10 July 2016 - Published in Biogeosciences Discuss.: 25 July 2016

Revised: 21 December 2016 - Accepted: 4 January 2017 - Published: 26 January 2017

\begin{abstract}
The current generation of marine biogeochemical modules in Earth system models (ESMs) considers mainly the effect of marine biota on the carbon cycle. We propose to also implement other biologically driven mechanisms in ESMs so that more climate-relevant feedbacks are captured. We classify these mechanisms in three categories according to their functional role in the Earth system: (1) "biogeochemical pumps", which affect the carbon cycling; (2) "biological gas and particle shuttles", which affect the atmospheric composition; and (3) "biogeophysical mechanisms", which affect the thermal, optical, and mechanical properties of the ocean. To resolve mechanisms from all three classes, we find it sufficient to include five functional groups: bulk phyto- and zooplankton, calcifiers, and coastal gas and surface mat producers. We strongly suggest to account for a larger mechanism diversity in ESMs in the future to improve the quality of climate projections.
\end{abstract}

\section{Introduction}

This "ideas and perspectives" paper deals with the role of marine biota in the climate system and the way this role can be adequately captured in the marine ecosystem components of Earth system models (ESMs) for climate research.

The representation of the marine ecosystem in ESMs used for climate projections has been significantly refined in recent years. Plankton, for example, has been split into functional groups, and physiological details, such as light or nutrient acclimation, have been added (e.g., Vichi et al., 2011; Aumont and Bopp, 2006; Aumont et al., 2015). Most of these modifications had been motivated by studies regarding the impact of climate change on marine ecosystems, or improving the representation of biogeochemical cycles, specifically the carbon cycle. Little attention, however, has been paid to other biologically mediated climate-relevant mechanisms, which we define as combinations of processes that lead to climate feedbacks. Here, we will present a framework to classify these biological-chemical-physical mechanisms and the functional groups that are necessary to describe them.

Many of today's marine biogeochemical models used in ESMs for climate projections include several phyto- and zooplankton functional groups; in some cases even variations in element or chlorophyll content of organic matter are allowed (see Laufkötter et al., 2015, for an overview). Apart from discussions about the appropriate degree of complexity in biogeochemical models (see Anderson, 2005; Flynn, 2006; and Le Quéré, 2006), even the most complex models "only" refine the representation of the marine carbon cycle. The climate-carbon cycle feedback, however, is just one of several feedback loops in which marine biota interacts with other components of the climate system.

These additional links are or may become important for the evolution of the climate system and should be implemented in ESMs. Thus, instead of adding more details to better represent just one mechanism, we should account for a "mechanism diversity". This way, the consequences of an altered functioning of the marine ecosystem with climate change will feed back on the climate system in multiple ways.

To adequately account for the proposed mechanism diversity, the first task is to come up with a list of relevant mechanisms. We define biologically driven mechanisms to be climate-relevant on timescales of contemporary climate 
change if they lead to a change in global energy (heat) content and distribution. These are, with decreasing levels of directness, (i) mechanisms with an immediate impact on the planetary albedo and/or sea surface temperature, (ii) mechanisms which change the content and distribution of greenhouse gases or ocean's turbulent viscosity, and (iii) mechanisms which change, for instance, the ocean's nutrient inventory with potential consequences for the marine carbon cycle and thus atmospheric greenhouse gas concentrations. Because the climate relevance of mechanisms on the third level is difficult to evaluate, we will limit this discussion to those of the first and second level. Even for these, quantitative estimates about the impact on the global energy budget are not available in all cases. Often, however, useful semiquantitative evaluations, for example on ocean circulation patterns, exist, and we will use them instead.

We will present a general framework that illustrates the links between the marine biota, the mechanisms, and the larger feedback loops in the climate system in a systematic way. Within this framework, individual processes as part of the mechanisms will be described only briefly, and only if they are indispensable for a basic understanding. Our list of processes cannot be complete, yet all mechanisms will be presented at a comparable level of abstraction. We believe that the framework will prove a useful basis for classification, even if additional biological climate-relevant mechanisms are discovered.

\section{What is needed: a classification of biologically driven mechanisms}

We adopt the idea to split the marine biota into different groups, but in contrast to previous approaches, we classify them according to their functional role in the climate system. The functions these organism groups carry are drivers of climate-relevant mechanisms.

This leads us to three classes of mechanisms (M1-M3) that generate climate feedbacks (see Fig. 1). For each class we briefly explain the main mechanisms, present the key organisms involved, and highlight the climate relevance. Finally, we describe the functional groups needed to represent this mechanism in ESMs (Table 1).

\section{M1 - biogeochemical pumps}

The first class of mechanisms comprises the marine part of the carbon cycle, including the organic carbon pump, the microbial carbon pump, and the alkalinity pump.

The organic carbon pump includes the processes related to the uptake of carbon dioxide in the upper ocean and the sinking of organically bound carbon to deeper waters. Three main organism groups are involved - phytoplankton, zooplankton, and bacteria. Phytoplankton drives the carbon cycle because inorganic carbon is transferred to organic carbon via photosynthesis and zooplankton decisively contributes to carbon export to the deeper ocean via fecal pellet production. Bacteria decompose the organic matter while it is sinking down and thereby determine the efficiency of the organic carbon pump. The climate relevance of the organic carbon pump has been evaluated in several model studies; rough estimates suggest that atmospheric $\mathrm{CO}_{2}$ levels would rise by approximately $200 \mathrm{ppmv}$ after a complete shutdown of the organic carbon pump (Volk and Hoffert, 1985; Broecker and Peng, 1986). As part of the climate-carbon cycle feedback (Friedlingstein et al., 2006), this mechanism is well known and regarded as the most important marine biologically driven mechanism. To capture the organic carbon pump in ESMs, two functional groups are, in principle, sufficient a bulk phytoplankton and a bulk zooplankton group to describe the transformation process from inorganic to organic matter and the sinking of the latter. All additional functional groups that are needed for other mechanisms, however, will also contribute (see Table 1). Bacteria do not need to be explicitly included as a key group to adequately represent the organic carbon pump because bacterial decomposition can be assumed to be roughly proportional to the available organic matter.

The microbial carbon pump describes the pathway from more easily degradable to refractory organic carbon by microbes (e.g., Jiao et al., 2010). These organisms transform dissolved or particulate organic carbon into compounds that are resistant towards degradation and are therefore stored for thousands of years. The refractory organic carbon pool is large and comparable to the atmospheric $\mathrm{CO}_{2}$ reservoir (Hansell et al., 2009), but it will have little impact on the climate system on timescales of several hundreds of years, unless an imbalance between sources and sinks evolves. Although it has been speculated that such changes may occur under ocean acidification and eutrophication (Jiao et al., 2014), there is insufficient knowledge to account for the microbial carbon pump and the corresponding functional groups in ESMs. In addition, no evaluation of the relevance of this pump with respect to contemporary climate change exists yet.

The alkalinity pump is another essential part of the marine carbon cycle because this mechanism alters the carbonate chemistry in the ocean. Organisms that affect the carbonate equilibrium are calcifying species, forming calcite or aragonite shells. They occur in the open ocean (e.g., coccolithophores) as well as in shallow regions (e.g., corals), where they "consume" alkalinity and release $\mathrm{CO}_{2}$ during the calcification process, causing a decrease in alkalinity. Since alkalinity is the capacity of the ocean to buffer acids and sets the limit of how much $\mathrm{CO}_{2}$ can be stored, changes in alkalinity have consequences for $\mathrm{CO}_{2}$ storage. While the quantitative impact of the alkalinity pump on climate is currently unclear, its role via the "calcification feedback" on atmospheric $\mathrm{CO}_{2}$ concentrations is assumed to be large (Zhang and Cao, 2016). Among the calcifiers, coccolithophores are the most 
important group (see, e.g., Rost and Riebesell, 2004) and mainly responsible for the vertical gradient in alkalinity. When coccolithophores die, they sink down to the deeper part of the ocean, where the calcareous shells dissolve and the alkalinity increases. Other calcifying organism groups have been shown to be regionally important (see, e.g., Baumann et al., 2004; Kleypas et al., 2006) or are assumed to be relevant for aragonite (Gangstøet al., 2008) but presumably only marginally for climate dynamics. To represent the alkalinity pump in ESMs, calcifiers need to be included to generate the vertical alkalinity gradient and to adequately resolve the carbonate chemistry. From a climate perspective, the gain from representing calcifiers by more than one key group might be relatively small unless regional ESMs are applied. With one additional key group, the calcifiers, represented by coccolithophores, the basic features of the alkalinity pump would be captured.

\section{M2 - biological gas and particle shuttles}

The second class of mechanisms, the biological gas and particle shuttles, addresses the impact of the marine biosphere on the atmosphere due to emission of gases and particles. These substances belong to the group of "short-lived climate-relevant air contaminants" (SCCs), a subset of shortlived health- and climate-relevant air contaminants (SHCCs), sensu Pöschl and Shiraiwa (2015). They may act as aerosols, influencing cloud formation. They may also affect the atmospheric chemistry or influence the thermodynamics as greenhouse gases.

Particulate SCCs of marine biogenic origin directly affecting cloud formation are called "marine biogenic primary aerosols". These include entire organisms, like phytoplankton cells or organisms' remnants, or "exudates", which are substances secreted by organisms (e.g., Knopf et al., 2011; Burrows et al., 2013; Wilson et al., 2015). Although the research area of marine biogenic aerosols is relatively new, recent studies suggest that, at least on a regional scale, ocean biota strongly influences the concentrations of cloud droplets with significant consequences for the reflected shortwave radiation (McCoy et al., 2015). Thus, ocean biota as a source for primary aerosols can directly contribute to the cloudalbedo feedback. As a first approximation, no additional functional group needs to be added in ESMs; a fraction of those organisms in the surface layer that are implemented in ESMs may serve as a source for primary aerosols anyway.

Gaseous SCCs may be involved in aerosol formation or participate in ozone reactions. The most important gaseous SCCs produced by marine organisms are dimethyl sulfide (DMS) and short-lived halocarbons. For both of these it is meaningful to distinguish open and coastal ocean sources since their efficiency in gas release is highly dissimilar and different organism groups are involved. DMS (or its precursor) is produced by "open ocean" (coccolithophores) and "coastal" phytoplankton (Phaeocystis) groups (e.g., Barnard et al., 1984; Malin et al., 1993). Zooplankton and bacteria are involved in the DMS shuttle (Reisch et al., 2011) and, similar to the organic carbon pump, bacteria determine the efficiency to a large extent. Short-lived bromine halocarbons are associated with "open ocean" phytoplankton and "coastal" macroalgae (e.g., Moore et al., 1996; Nightingale et al., 1995; Carpenter and Liss, 2000).

Dimethyl sulfide (DMS) is a precursor of sulfate aerosols and involved in the cloud-albedo feedback (e.g., Charlson et al., 1987; Ayers and Cainey, 2008), although its climate relevance is still under discussion (e.g., Quinn and Bates, 2011). Local effects on shortwave radiation of DMS emission by a phytoplankton bloom can induce cooling of up to $15 \mathrm{~W} \mathrm{~m}^{-2}$ at the top of the atmosphere; such a high value is usually associated with heavily air-polluted regions (Meskhidze and Nenes, 2006). The global direct radiative effect of DMS has been estimated to be $-0.23 \mathrm{~W} \mathrm{~m}^{-2}$, and the indirect as $-0.76 \mathrm{~W} \mathrm{~m}^{-2}$. The contribution of primary producers via DMS production to sources of natural aerosols is therefore larger than those from sea salt or volcanoes, for example (Rap et al., 2013).

Short-lived halocarbons, particularly brominated substances, are important SCCs because they destroy ozone and thereby significantly change the radiative forcing (Sturges et al., 2000; Saiz-Lopez et al., 2012; Laube et al., 2008). The radiative effect is estimated to be about $-0.2 \mathrm{~W} \mathrm{~m}^{-2}$ and thus larger than the one by the widely known anthropogenically produced long-lived halocarbons such as CFCs (Hossaini et al., 2015).

For both DMS and short-lived halocarbons, it is crucial to correctly represent the spatial patterns of marine primary production and corresponding SCCs (e.g., Stemmler et al., 2015, for halocarbons). To capture the gradient between coastal and open ocean, an additional model compartment, the "coastal gas producers", has to be included in ESMs. A relatively easy way to describe them in a model is by allowing the uptake of nutrients from sediment or deepest model layer and by prescribing relatively high emissions per unit biomass. Even if different types of organisms are involved in the coastal production of DMS and short-lived halocarbons, one functional group is sufficient because coastal patterns of the two SCCs do not differ clearly. The group of open-ocean organisms can be represented by either coccolithophores in the case of DMS or by a "bulk phytoplankton" group in the case of halocarbons (although parameterizations are necessary because only part of the entire bulk phytoplankton produces halocarbons). Just like for the organic carbon pump, bacteria do not need to be explicitly considered for the DMS shuttle; zooplankton, the other group involved in DMS release, is included anyway because of its role in the organic carbon pump.

Lastly, there are a number of greenhouse gases of marine biogenic origin, notably $\mathrm{CO}_{2}$. This gas is respired by all organisms and is more or less automatically captured in ESMs through the loss rate of all functional groups. In addition to $\mathrm{CO}_{2}$, another important long-lived greenhouse gas is $\mathrm{N}_{2} \mathrm{O}$, 
which has a global warming potential of a 100 -year time horizon that is approximately 300 times higher compared to $\mathrm{CO}_{2}$ (Myhre et al., 2013). About $20 \%$ of the global production of $\mathrm{N}_{2} \mathrm{O}$ is of marine origin (Denman et al., 2007), mediated by microbes. $\mathrm{N}_{2} \mathrm{O}$ is released mainly during nitrification, (the oxidation of ammonium to nitrate under oxic conditions) and, to a lower extent, during denitrification (the reduction from nitrate to dinitrogen gas under anoxic conditions) (Freing et al., 2012). Two organism groups, bacteria and archaea, are involved in these transformation processes. So far, our knowledge regarding the spatial variations in the occurrence of the organisms involved and the respective rates is too fragmented to explicitly describe these processes in models. Instead, these bacterial transformation processes can be implicitly considered in the same way as done for other mechanisms (by choosing turnover rates that are proportional to the available resources); thus, no further model compartment is necessary.

Marine sources of other biogenic greenhouse gases like $\mathrm{CH}_{4}$ are mainly related to marine microorganisms (e.g., Valentine, 2011). To the best of our knowledge, the effect of these greenhouse gases such as $\mathrm{CH}_{4}$ on the climate system may be considered negligible because the marine sources are small compared to the terrestrial or anthropogenic ones. Thus, it is currently not justifiable to add more model compartments.

\section{M3 - biogeophysical mechanisms}

The third class of biologically driven climate-relevant mechanisms includes all biogeophysical mechanisms. These mechanisms comprise changes in thermal, optical, and mechanical properties of the ocean, predominantly caused by phytoplankton species. Among them, positively buoyant cyanobacteria are particularly important because they can produce surface mats of up to several millions of square kilometers (e.g., Capone et al., 1998). Such surface mats significantly change light absorption, impacting the surface mixed layer heat balance (e.g., Sathyendranath et al., 1991; Kahru et al., 1993). In addition, they increase the albedo (e.g., Kahru et al., 1993), alter the turbulent viscosity, and reduce vertical mixing (e.g., Jöhnk et al., 2008). Surface mats may also reduce the air-sea gas exchange, if we assume effects similar to surface microlayers (e.g., Liss and Duce, 2005).

The climate impact of the light absorption mechanism has been only assessed for neutrally buoyant phytoplankton groups so far. Their impact alone, however, is significant: pronounced effects on oceanic and atmospheric temperature, circulation patterns, cloudiness, humidity, precipitation and evaporation, and sea ice cover (Patara et al., 2012) as well as El Niño-Southern Oscillation (ENSO) dynamics (e.g., Jochum et al., 2010) have been shown to be influenced through light absorption. The strong response triggered by this mechanism results from multiple feedback loops that involve different Earth system components.
Table 1. Organism groups that drive climate mechanisms: M1: biogeochemical pumps; M2: gas and particle shuttle and M3: biogeophysical mechanisms. Note that zooplankton is partly involved in the production of DMS due to grazing and thus checked in parenthesis.

\begin{tabular}{llll}
\hline Organism groups & M1 & M2 & M3 \\
\hline Bulk phytoplankton & $\checkmark$ & $\checkmark$ & $\checkmark$ \\
Bulk zooplankton & $\checkmark$ & $(\checkmark)$ & - \\
Calcifier & $\checkmark$ & $\checkmark$ & $\checkmark$ \\
Coastal gas producer & $\checkmark$ & $\checkmark$ & $\checkmark$ \\
Surface mat producer & $\checkmark$ & $\checkmark$ & $\checkmark$ \\
\hline
\end{tabular}

Rough estimates indicate that changes in albedo through phytoplankton, specifically coccolithophores, can result in a cooling by roughly $0.2 \mathrm{~W} \mathrm{~m}^{-2}$ globally (Tyrrell et al., 1999). A more sophisticated evaluation, however, points towards a negligible impact on the albedo, at least on the basin scale (Gondwe et al., 2001). In any case there is a direct link to the albedo-temperature feedback (Watson and Lovelock, 1983).

Unfortunately, the effect on climate through biologically induced changes in the ocean's turbulent viscosity has not been addressed yet. Idealized model studies, however, suggest that a biologically induced increase or decrease in turbulent viscosity by surface mats can affect ocean circulation patterns on a basin scale (Sonntag, 2013).

To account for biogeophysical aspects in ESMs, one additional key group, "surface mat producers", is needed. Cyanobacteria are a good candidate to represent this group. They possess the trait "positive buoyancy", which is not shared with other phytoplankton. Clearly, all other groups of marine primary producers that are explicitly described in ESMs have an impact on light absorption, too, but by distinguishing neutrally or negatively from positively buoyant phytoplankton, a more realistic representation of the light absorption feedback will be achieved.

To summarize, including the abovementioned five functional groups (Table 1) will meet the requirements for an adequate representation of biologically driven mechanisms in ESMs.

\section{What changes may occur in the future: sensitivity of marine biota to climate stressors}

The marine biota itself, as well as the strength of the individual mechanisms, may evolve under climate change due to changes in the three climate stressors - temperature, $\mathrm{pH}$, and oxygen. As a rule of thumb, higher temperatures increase the metabolic rates of organisms. Lower $\mathrm{pH}$ may increase the growth of non-calcifiers and decrease that of calcifiers (e.g., Raven, 2011). Low oxygen concentrations will particularly impact higher trophic levels and microbial processes. In principle, however, the response will be species-specific. 

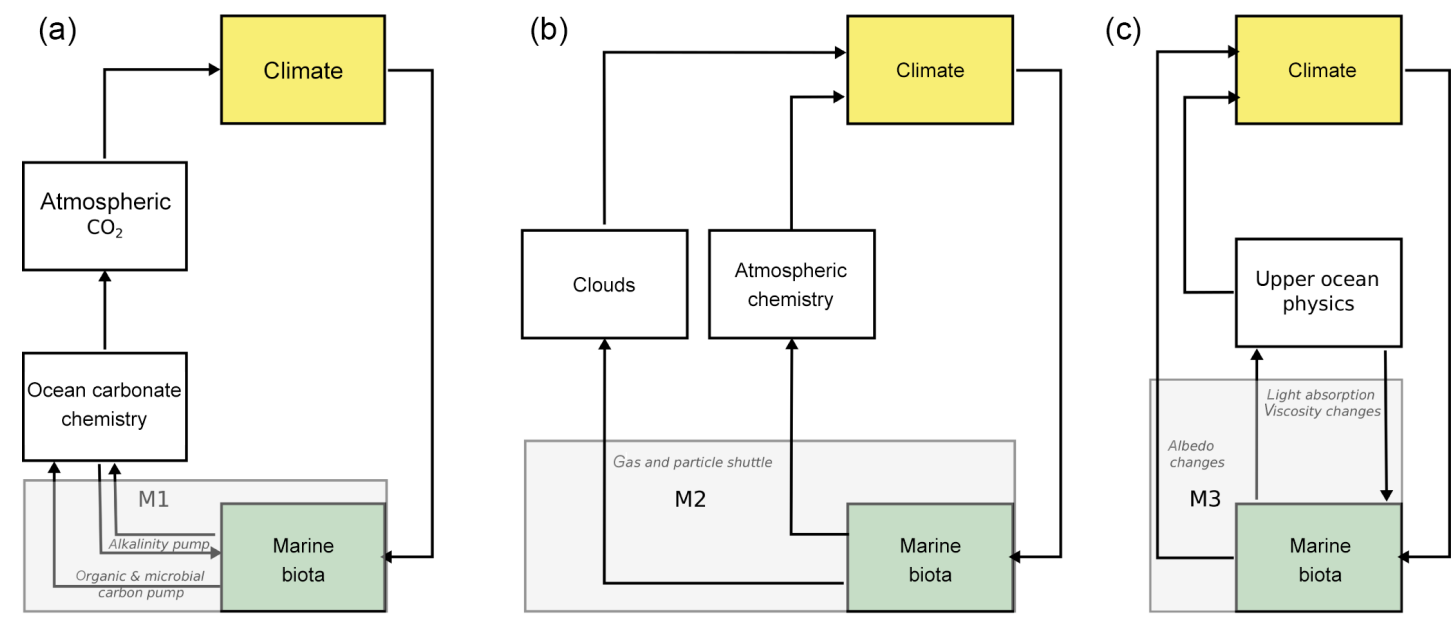

Figure 1. Major global climate feedback loops, based on the three classes of mechanisms (light grey-shaded boxes), driven by marine biota (green-shaded boxes). Only links originating from the marine biota are shown; additional inter- and cross-links between the different boxes are omitted for clarity. (a) The three mechanisms (the organic and the microbial carbon pump, and the alkalinity pump) affect the $\mathrm{CO}_{2}$ inventory in the ocean, which in turn leads to changes in atmospheric $\mathrm{CO}_{2}$ and thus in climate. An altered global climate influences the marine biota (through, for example, changes in SST, near-surface stratification, and circulation patterns), closing the marine part of the climate-carbon cycle feedback loop which also includes the $\mathrm{CO}_{2}$ calcification feedback. (b) The gas and particle shuttle alters cloud formation rates and distribution as well as atmospheric chemistry. There is a complex interplay between different atmospheric components that ultimately lead to climate change, again with consequences for the marine biota. A number of atmospheric feedbacks (e.g., the cloudalbedo feedback, the long-wave radiation feedback, the chemistry feedbacks) are involved in this loop. Note that the influence of marine biota on local cloud cover is not illustrated here. (c) Two biogeophysical mechanisms (based on light absorption and turbulent viscosity changes) directly affect the upper ocean physics such as heat distribution and circulation and hence the biota. The third one (albedo changes) has a direct effect on the planetary radiation budget, which influences in turn the marine biota.

Among phytoplankton, cyanobacteria are assumed to strongly benefit from climate change, and thus they are expected to become more abundant in the future (e.g., O'Neil et al., 2012; Hense et al., 2013). In particular, a moderate rise in sea surface temperature (Fu et al., 2014), as well as a decrease in $\mathrm{pH}$, will favor their growth conditions (Hutchins et al., 2007). More cyanobacteria will intensify the biogeophysical feedback mechanisms and possibly the particle shuttle. The response of other phytoplankton to $\mathrm{pH}$ is not well understood. While ocean acidification may significantly affect calcifiers and the calcification rate, the response is not uniform (see Kleypas et al., 2006) and genetic adaptation (Lohbeck et al., 2012) might outweigh the negative consequences of a decreasing $\mathrm{pH}$. Ocean acidification (but also increasing temperature) may directly affect DMS producing organisms and thus outgassing of DMS: depending on the grazing pressure, DMS production seems to be either enhanced (Kim et al., 2010) or reduced (Archer et al., 2013). A strong response of the climate system to reduced DMSproduction on radiative forcing has been proposed (Six et al., 2013).

Sensitivity to climate stressors has also been described for many microbial organisms. Nitrifiers are one example. For lower $\mathrm{pH}$, nitrification and therefore $\mathrm{N}_{2} \mathrm{O}$ production are strongly reduced (Beman et al., 2011). It is expected nevertheless that the production of $\mathrm{N}_{2} \mathrm{O}$ will increase in the future
(Naqvi et al., 2010) due to the expansion of oxygen minimum zones (Stramma et al., 2008), taking into account that the highest $\mathrm{N}_{2} \mathrm{O}$ production usually occurs at the anoxic-oxic interface. Another example of microbes that seem to benefit from climate change is those involved in the aerobic decomposition of organic matter. A rise in temperature and a drop in $\mathrm{pH}$ stimulates bacterial turnover rates (Pomeroy and Deibel, 1986; Piontek et al., 2010). With enhanced remineralization, the efficiency of the organic carbon pump will be reduced, altering the ocean's carbon uptake capacity (Segschneider and Bendtsen, 2013). On the other hand, bacterial decomposition rates may be affected through a decrease in oxygen concentrations with an expansion of oxygen minimum zones (Stramma et al., 2008). It is still unclear, however, whether low oxygen concentrations will impair bacterial degradation of organic matter or not (see, e.g., Kristensen et al., 1995; Devol and Hartnett, 2001).

In addition to the immediate effect of climate stressors on ocean biota, we expect significant alterations in the environment with potentially large long-term consequences on the organisms and biologically driven mechanisms. For example, the organic carbon pump will likely be altered by changes in stratification (Steinacher et al., 2009), the ocean's molecular viscosity (Taucher et al., 2014), and plankton community composition (see, e.g., Laufkötter et al., 2016). The alkalinity pump may be affected by changes in freshwater input or 
Table 2. Different marine biosphere modules (MBMs) in Earth system models (ESMs) that participated in CMIP5 (Arora et al., 2013 ; Laufkötter et al., 2015): OCMIP: Wu et al. (2013); CMOC: Christian et al. (2010); BEC: Moore et al. (2013); TOPAZ2: Supplement of Sarmiento et al. (2010), Dunne et al. (2013); Diat-HadOCC: Palmer and Totterdell (2001); HadGEM2-ES: The HadGEM2 Development Team (2011); PELAGOS: Vichi et al. (2007), Vichi et al. (2011); PISCES: Aumont and Bopp (2006), Lengaigne et al. (2009), Aumont et al. (2015); NPZD: Watanabe et al. (2011), Kawamiya et al. (2000); HAMOCC: Maier-Reimer et al. (2005), Ilyina et al. (2013). We only use the most recent peer-reviewed reference of each MBM. MBMs are only listed once, even though some of them are used in more than one ESM. The numerals refer to the biologically driven mechanisms while P, Z, C, cG, S, and B denote the organism groups phytoplankton, zooplankton, calcifiers, coastal gas producers, surface mat producers, and bacteria, respectively. Organism groups that are not explicitly described but parameterized are in parentheses. Checkmarks with additions refer to the biogeochemical carbon pump (bcp), DMS or $\mathrm{N}_{2} \mathrm{O}$ (specific SCCs), light absorption by neutrally/negatively buoyant phytoplankton (LA-nbp), or the numbers of explicitly described functional groups. In PISCES, the SCCs are not included by default but available through additional modules.

\begin{tabular}{|c|c|c|c|c|c|c|c|c|c|c|}
\hline \multirow[b]{2}{*}{ ESMs } & \multirow[b]{2}{*}{ MBMs } & \multicolumn{3}{|c|}{ Mechanisms } & \multicolumn{6}{|c|}{ Functional groups } \\
\hline & & M1 & M2 & M3 & $\mathrm{P}$ & $\mathrm{Z}$ & $\mathrm{C}$ & $\mathrm{cG}$ & $\mathrm{S}$ & B \\
\hline BCC_CSM1.1 & OCMIP & $\checkmark^{\text {bcp }}$ & - & - & - & - & - & - & - & - \\
\hline CanESM1 & $\mathrm{CMOC}$ & $\checkmark$ & _ & _ & $\checkmark^{1}$ & $\checkmark^{1}$ & _ & _ & _- & - \\
\hline CESM1 & $\mathrm{BEC}$ & $\checkmark$ & _ & $\checkmark^{\text {LA-nbp }}$ & $\checkmark^{3}$ & $\checkmark^{1}$ & $(\checkmark)$ & _ & _- & _- \\
\hline ESM2M/ESM2G & TOPAZ2 & $\checkmark$ & - & $\checkmark$ LA-nbp & $\checkmark^{3}$ & $(\checkmark)$ & $(\checkmark)$ & - & - & - \\
\hline HadGEM2-ES & Diat-HadOCC & $\checkmark$ & $\checkmark$ DMS & - & $\checkmark^{2}$ & $\checkmark^{1}$ & $(\checkmark)$ & - & - & - \\
\hline CMCC-CESM & PELAGOS & $\checkmark^{\text {bcp }}$ & - & $\checkmark$ LA-nbp & $\checkmark^{3}$ & $\checkmark^{3}$ & - & - & - & $\checkmark^{1}$ \\
\hline IPSL-CM5A & PISCES & $\checkmark$ & $\left(\checkmark^{\mathrm{DMS}, \mathrm{N}_{2} \mathrm{O}}\right)$ & $\checkmark$ LA-nbp & $\checkmark^{2}$ & $\checkmark^{2}$ & $(\checkmark)$ & - & - & - \\
\hline MIROC-ESM & NPZD & $\checkmark^{\text {bcp }}$ & - & - & $\checkmark^{1}$ & $\checkmark^{1}$ & - & - & - & - \\
\hline MPI-ESM & HAMOCC & $\checkmark$ & $\checkmark$ DMS & - & $\checkmark^{1}$ & $\checkmark^{1}$ & $(\checkmark)$ & - & - & - \\
\hline
\end{tabular}

evaporation (see Steinacher et al., 2009; Jiang et al., 2014). Overall, it is very certain that the relative abundance of some phytoplankton organisms will change as a result of their response to climate stressors and altered environmental conditions. Such a shift in community composition will affect the strength of all three classes of mechanisms, and with that their relative importance within the climate system.

\section{What is currently done: the state of the art}

Today's ESMs represent the first class of biologically driven climate-relevant mechanisms, the biogeochemical pumps (in particular the organic carbon pump), reasonably well (Table 2). Most of these models explicitly consider phyto- and zooplankton, which are described in such a way that the model results give reasonable values for export production (see Ilyina et al., 2013; Palmer and Totterdell, 2001). The carbonate chemistry is also relatively well represented, even though calcifiers are not explicitly included but are parameterized by assuming that they constitute a certain proportion of bulk phytoplankton.

The second class of mechanisms, which affect the atmospheric composition, has received less attention. Some ESMs do consider DMS and $\mathrm{N}_{2} \mathrm{O}$ (Table 2), and their results suggest significant changes in the production with consequences for the climate system in the future (e.g., Six et al., 2013; Martinez-Rey et al., 2015). Other marine biologically produced SCCs (except $\mathrm{CO}_{2}$ ) and aerosols are usually not included, but there are a number of recent modeling activi- ties in which the pertinent processes have been implemented, and the climate impact of these substances has been partially evaluated (e.g., Kirkevåg et al., 2013; Stemmler et al., 2014, 2015; Hossaini et al., 2015). The largest deficiency of ESMs in this respect is that primary production is still not sufficiently well represented, in particular in coastal regions (e.g., Schneider et al., 2008; Anav et al., 2013). Even though the respective ESMs and global marine biogeochemical models have become more and more complex in recent years (see Aumont et al., 2003; Le Quéré et al., 2005; Dunne et al., 2013; Buitenhuis et al., 2013), the situation has only marginally improved. Not surprisingly, models generally fail to simulate SCC concentrations and air-sea fluxes on the shelf (see Halloran et al., 2010; Stemmler et al., 2015); much could be gained if coastal primary production were captured more realistically.

Finally, the third class of mechanisms, the marine biogeophysical mechanisms, is hardly addressed in today's ESMs; so far, only half of them include the light absorption mechanism involved in the feedback between the biota and temperature (Table 2). Recent studies with neutrally or negatively buoyant phytoplankton indicate that consequences for the upper ocean heat balance and the climate system are substantial (e.g., Patara et al., 2012; Lengaigne et al., 2009). Thus, the effects might be even stronger if positively buoyant organisms are added; whether organisms stay at the surface or whether they are homogeneously distributed in the surface mixed layer makes a large difference for the upper ocean heat budget (e.g., Sonntag and Hense, 2011). None of today's 
ESMs or coupled global biogeochemical ocean circulation models account for other biogeophysical effects, i.e. changes in albedo and turbulent viscosity.

\section{What needs to be done: an alternative way to design the marine biological component of ESMs}

The mechanism diversity in today's Earth system models is low, although the marine biological modules include a relatively large number of biological variables. In fact, most of the models include more functional groups than we think are necessary to capture all three classes of mechanisms. Hence, it should be relatively easy to increase the mechanism diversity and allow for the desired more complete description of links between marine biota and other Earth system components.

Given the current level of process understanding, we propose to keep the organic carbon and alkalinity pumps and add at least one gas shuttle, as well as light absorption. In parallel, pilot studies with biogenic primary aerosols should be conducted and sensitivity experiments with the other two biogeophysical mechanisms should be performed. Further mechanisms may have to be added with improved process knowledge or increasing model resolution, while others may have to be omitted if they turn out to be negligible. Hence, the list of mechanisms is not fixed.

To capture the suggested mechanisms in ESMs, only a few additional functional groups are needed. Calcifiers and coastal gas and surface mat producers should be explicitly taken into account. Parameterizing calcification may work out for today's ocean, but in climate change scenario experiments, this parameterization may no longer be appropriate. Under future acidified conditions, the composition of calcifying and non-calcifying species of the phytoplankton as well as the growth behavior of calcifiers may significantly change due to competing selection pressures. To allow for such shifts in community composition, calcifiers should be explicitly implemented as a separate state variable. Surface mat producers, represented by cyanobacteria, are included in a few ESMs (e.g., Dunne et al., 2013) because of their role as nitrogen fixers in the nitrogen cycle. Their role in the biogeophysical mechanisms is not included, and we suggest to account for that by adding the trait "surface buoyancy".

Our knowledge of other sensitivities is still underdeveloped, so it would be premature, for example, to include functional dependencies of the $\mathrm{pH}$ effect on phytoplankton growth. The same is true for our knowledge about genetic adaptation towards climate stressors.

\section{Summary and conclusions}

We distinguish three main classes of biologically driven climate-relevant mechanisms. We argue that a fundamentally different kind of progress will be achieved if members of all classes of mechanisms are included in ESMs for climate projections. To resolve the mechanisms, five functional groups are needed: bulk phyto- and zooplankton, calcifiers, and coastal gas and surface mat producers. Thus, our suggested marine biosphere module for ESMs may be even less complex than those modules currently used for climate projections. However, in contrast to these state-of-the-art concepts, a wider range of important links between the marine biosphere and other Earth system components - and consequently more feedbacks - is allowed.

We believe that mechanism diversity is better suited to account for possible changes in ocean biota and consequences for the climate system. With global warming and ocean acidification, the marine biota will be altered (e.g., Hallegraeff, 2010). Since key groups respond differently to climate change, the strength of biologically driven mechanisms will also change, as will links to other Earth system components. The feedback loops associated with these mechanisms will be altered accordingly. Thus, to evaluate the response of the climate system, the mechanism diversity should be increased.

Competing interests. The authors declare that they have no conflict of interest.

Acknowledgements. Numerous discussions with and valuable comments from Aike Beckmann are highly appreciated. Thanks also go to three anonymous reviewers and the editor for helpful comments as well as to Christine Nam for proofreading. An earlier version of this paper was commented on by Dallas Murphy, Jochem Marotzke, and the participants of the "Advanced Scientific Writing Course for Faculty" that took place at the Max Planck Institute for Meteorology in Hamburg. Inga Hense was financed through Cluster of Excellence "CliSAP" (EXC177), University of Hamburg, funded by the German Science Foundation (DFG). Part of this study was also funded by German BMBF project SOPRAN (Surface Ocean Processes in the Anthropocene), SOPRAN 03F0662E. Sebastian Sonntag was supported by the DFG-funded SPP 1689 "Climate Engineering".

Edited by: C. Heinze

Reviewed by: four anonymous referees

\section{References}

Anav, A., Friedlingstein, P., Kidston, M., Bopp, L., Ciais, P., Cox, P., Jones, C., Jung, M., Myneni, R., and Zhu, Z.: Evaluating the land and ocean components of the global carbon cycle in the CMIP5 Earth System Models, J. Climate, 26, 6801-6843, 2013.

Anderson, T. R.: Plankton functional type modelling: running before we can walk?, J. Plankton Res., 27, 1073-1081, 2005.

Archer, S. D., Kimmance, S. A., Stephens, J. A., Hopkins, F. E., Bellerby, R. G. J., Schulz, K. G., Piontek, J., and Engel, A.: Contrasting responses of DMS and DMSP to ocean acidification in Arctic waters, Biogeosciences, 10, 1893-1908, doi:10.5194/bg10-1893-2013, 2013. 
Arora, V., Boer, G., Friedlingstein, P., Eby, M., Jones, C., Christian, J., Bonan, G., Bopp, L., Brovkin, V., Cadule, P., Hajima, T., Ilyina, T., Lindsay, K., Tjiputra, J. F., and Wu, T.: Carbonconcentration and carbon-climate feedbacks in CMIP5 Earth system models, J. Climate, 26, 5289-5314, 2013.

Aumont, O. and Bopp, L.: Globalizing results from ocean in situ iron fertilization studies, Global Biogeochem. Cy. 20, GB2017, doi:10.1029/2005GB002591, 2006.

Aumont, O., Maier-Reimer, E., Blain, S., and Monfray, P.: An ecosystem model of the global ocean including $\mathrm{Fe}$, $\mathrm{Si}$, P colimitations, Global Biogeochem. Cy., 17, 1060, doi:10.1029/2001GB001745, 2003.

Aumont, O., Ethé, C., Tagliabue, A., Bopp, L., and Gehlen, M.: PISCES-v2: an ocean biogeochemical model for carbon and ecosystem studies, Geosci. Model Dev., 8, 2465-2513, doi:10.5194/gmd-8-2465-2015, 2015.

Ayers, G. and Cainey, J.: The CLAW hypothesis: a review of the major developments, Environ. Chem., 4, 366-374, 2008.

Barnard, W., Andreae, M., and Iverson, R.: Dimethylsulfide and Phaeocystis poucheti in the southeastern Bering Sea, Cont. Shelf Res., 32, 103-113, 1984.

Baumann, K.-H., Böckel, B., and Frenz, M.: Coccolith contribution to South Atlantic carbonate sedimentation, in: Coccolithophores: from molecular processes to global impact, edited by: Thierstein, R. and Young, J. R., 367-402, Springer, 2004.

Beman, J. M., Chow, C.-E., King, A. L., Feng, Y., Fuhrman, J. A., Andersson, A., Bates, N. R., Popp, B. N., and Hutchins, D. A.: Global declines in oceanic nitrification rates as a consequence of ocean acidification, P. Natl. Acad. Sci. USA, 108, 208-213, 2011.

Broecker, W. and Peng, T.: Carbon cycle: 1985 Glacial to interglacial changes in the operation of the global carbon cycle, Radiocarbon, 28, 309-327, 1986.

Buitenhuis, E., Hashioka, T., and Le Quéré, C.: Combined constraints on global ocean primary production using observations and models, Global Biogeochem. Cy., 27, 847-858, 2013.

Burrows, S. M., Hoose, C., Pöschl, U., and Lawrence, M. G.: Ice nuclei in marine air: biogenic particles or dust?, Atmos. Chem. Phys., 13, 245-267, doi:10.5194/acp-13-245-2013, 2013.

Capone, D., Subramaniam, A., Montoya, J., Voss, M., Humborg, C., Johansen, A., Siefert, R., and Carpenter, E.: An extensive bloom of the $\mathrm{N}_{2}$-fixing cyanobacterium Trichodesmium erythraeum in the central Arabian Sea, Mar. Ecol.-Prog. Ser., 172, 281-292, 1998.

Carpenter, L. and Liss, P. S.: On temperate sources of bromoform and other reactive organic bromine gases, J. Geophys. Res.Ocean., 105, 20539-20547, 2000.

Charlson, R. J., Lovelock, J. E., Andrae, M. O., and Warren, S. G.: Oceanic phytoplankton, atmospheric sulfur, cloud albedo and climate, Nature, 326, 655-661, 1987.

Christian, J. R., Arora, V. K., Boer, G. J., Curry, C. L., Zahariev, K., Denman, K. L., Flato, G. M., Lee, W. G., Merryfield, W. J., Roulet, N. T., and Scinocca, J. F.: The global carbon cycle in the Canadian Earth system model (CanESM1): Preindustrial control simulation, J. Geophys. Res.-Biogeo., 115, G03014, doi:10.1029/2008JG000920, 2010.

Denman, K. L., Brasseur, G., Chidthaisong, A., Ciais, P., Cox, P., Dickinson, R., Hauglustaine, D., Heinze, C., Holland, E., Jacob, D., Lohmann, U., Ramachandran, S., da Silva Dias, P., Wofsy, S., and Zhang, X.: Couplings Between Changes in the Climate System and Biogeochemistry, in: Climate Change 2007: The Physical Science Basis. Contribution of Working Group I to the Fourth Assessment Report of the Intergovernmental Panel on Climate Change, edited by: Solomon, S., Qin, D., Manning, M., Chen, Z., Marquis, M., Averyt, K., Tignor, M., and Miller, H., 498-587, Cambridge University Press, 2007.

Devol, A. H. and Hartnett, H. E.: Role of the oxygen-deficient zone in transfer of organic carbon to the deep ocean, Limnol. Oceanogr., 46, 1684-1690, 2001.

Dunne, J., John, J., Shevliakova, E., Stouffer, R., Krasting, J., Malyshev, S., Milly, P., Sentman, L., Adcroft, A., Cooke, W., and Dunne, K.: GFDL's ESM2 Global Coupled Climate-Carbon Earth System Models. Part II: Carbon System Formulation and Baseline Simulation Characteristics, J. Climate, 26, 2247-2267, 2013.

Flynn, K.: Reply to Horizons Article "Plankton functional type modelling: running before we can walk" Anderson (2005): II. Putting trophic functionality into plankton functional types, J. Plankton Res., 28, 873-875, 2006.

Freing, A., Wallace, D. W. R., and Bange, H. W.: Global oceanic production of nitrous oxide, Philos. T. R. Soc. B, 367, 12451255, 2012.

Friedlingstein, P., Cox, P., Betts, R., Bopp, L., Von Bloh, W., Brovkin, V., Cadule, P., Doney, S., Eby, M., and Fung, I.: Climate-carbon cycle feedback analysis: Results from the C4MIP model intercomparison, J. Climate, 19, 3337-3353, 2006.

Fu, F.-X., Yu, E., Garcia, N. S., Gale, J., Luo, Y., Webb, E. A., and Hutchins, D. A.: Differing responses of marine $\mathrm{N}_{2}$ fixers to warming and consequences for future diazotroph community structure, Aquat. Microbiol. Ecol., 72, 33-46, 2014.

Gangst $\varnothing$, R., Gehlen, M., Schneider, B., Bopp, L., Aumont, O., and Joos, F.: Modeling the marine aragonite cycle: changes under rising carbon dioxide and its role in shallow water $\mathrm{CaCO}_{3}$ dissolution, Biogeosciences, 5, 1057-1072, doi:10.5194/bg-5-10572008, 2008.

Gondwe, M., Klaassen, W., Gieskes, W., and Baar, H.: Negligible direct radiative forcing of basin-scale climate by coccolithophore blooms, Geophys. Res. Lett., 28, 3911-3914, 2001.

The HadGEM2 Development Team: G. M. Martin, Bellouin, N., Collins, W. J., Culverwell, I. D., Halloran, P. R., Hardiman, S. C., Hinton, T. J., Jones, C. D., McDonald, R. E., McLaren, A. J., O'Connor, F. M., Roberts, M. J., Rodriguez, J. M., Woodward, S., Best, M. J., Brooks, M. E., Brown, A. R., Butchart, N., Dearden, C., Derbyshire, S. H., Dharssi, I., Doutriaux-Boucher, M., Edwards, J. M., Falloon, P. D., Gedney, N., Gray, L. J., Hewitt, H. T., Hobson, M., Huddleston, M. R., Hughes, J., Ineson, S., Ingram, W. J., James, P. M., Johns, T. C., Johnson, C. E., Jones, A., Jones, C. P., Joshi, M. M., Keen, A. B., Liddicoat, S., Lock, A. P., Maidens, A. V., Manners, J. C., Milton, S. F., Rae, J. G. L., Ridley, J. K., Sellar, A., Senior, C. A., Totterdell, I. J., Verhoef, A., Vidale, P. L., and Wiltshire, A.: The HadGEM2 family of Met Office Unified Model climate configurations, Geosci. Model Dev., 4, 723-757, doi:10.5194/gmd-4-723-2011, 2011.

Hallegraeff, G. M.: Ocean climate change, phytoplankton community responses, and harmful algal blooms: a formidable predictive challenge, J. Phycol., 46, 220-235, 2010. 
Halloran, P. R., Bell, T. G., and Totterdell, I. J.: Can we trust empirical marine DMS parameterisations within projections of future climate?, Biogeosciences, 7, 1645-1656, doi:10.5194/bg-71645-2010, 2010.

Hansell, D. A., Carlson, C. A., Repeta, D. J., and Schlitzer, R.: Dissolved organic matter in the ocean: A controversy stimulates new insights, Oceanography, 22, 202-211, 2009.

Hense, I., Meier, H., and Sonntag, S.: Projected climate change impact on Baltic Sea cyanobacteria, Clim. Dynam., 119, 391-406, 2013

Hossaini, R., Chipperfield, M., Montzka, S., Rap, A., Dhomse, S., and Feng, W.: Efficiency of short-lived halogens at influencing climate through depletion of stratospheric ozone, Nat. Geosci., 8, 186-190, 2015.

Hutchins, D. A., Fu, F.-X., Zhang, Y., Warner, M. E., Feng, Y., Portune, K., Bernhardt, P. W., and Mulholland, M. R.: $\mathrm{CO}_{2}$ control of Trichodesmium $\mathrm{N}_{2}$ fixation, photosynthesis, growth rates, and elemental ratios: Implications for past, present, and future ocean biogeochemistry, Limnol. Oceanogr., 52, 1293-1304, 2007.

Ilyina, T., Six, K., Segschneider, J., Maier-Reimer, E., Li, H., and Núñnez Riboni, I. N.: Global ocean biogeochemistry model HAMOCC: Model architecture and performance as component of the MPI-Earth system model in different CMIP5 experimental realizations, J. Adv. Model. Earth Syst., 5, 287-315, 2013.

Jiang, Z.-P., Tyrrell, T., Hydes, D. J., Dai, M., and Hartman, S. E.: Variability of alkalinity and the alkalinity-salinity relationship in the tropical and subtropical surface ocean, Global Biogeochem. Cy., 28, 729-742, 2014.

Jiao, N., Herndl, G. J., Hansell, D. A., Benner, R., Kattner, G., Wilhelm, S. W., Kirchman, D. L., Weinbauer, M. G., Luo, T., Chen, F., and Azam, F.: Microbial production of recalcitrant dissolved organic matter: long-term carbon storage in the global ocean, Nat. Rev. Microbiol., 8, 593-599, 2010.

Jiao, N., Robinson, C., Azam, F., Thomas, H., Baltar, F., Dang, H., Hardman-Mountford, N. J., Johnson, M., Kirchman, D. L., Koch, B. P., Legendre, L., Li, C., Liu, J., Luo, T., Luo, Y.-W., Mitra, A., Romanou, A., Tang, K., Wang, X., Zhang, C., and Zhang, R.: Mechanisms of microbial carbon sequestration in the ocean - future research directions, Biogeosciences, 11, 52855306, doi:10.5194/bg-11-5285-2014, 2014.

Jochum, M., Yeager, S., Lindsay, K., Moore, K., and Murtugudde, R.: Quantification of the feedback between phytoplankton and ENSO in the Community Climate System Model, J. Climate, 23, 2916-2925, 2010.

Jöhnk, K., Huisman, D., Sharples, J., Sommeijer, B., Visser, P., and Stroom, J.: Summer heatwaves promote blooms of harmful cyanobacteria, Glob. Change Biol., 14, 495-512, 2008.

Kahru, M., Leppaenen, J.-M., and Rud, O.: Cyanobacterial blooms cause heating of the sea surface, Mar. Ecol.-Prog. Ser., 101, 1-7, 1993.

Kawamiya, M., Kishi, M., and Suginohara, N.: An ecosystem model for the North Pacific embedded in a general circulation model: Part I: Model description and characteristics of spatial distributions of biological variables, J. Marine Syst., 25, 129-157, 2000.

Kim, J.-M., Lee, K., Yang, E. J., Shin, K., Noh, J. H., Park, K., Hyun, B., Jeong, H.-J., Kim, J.-H., Kim, K. Y., Kim, M., Kim, H.C., Jang, P.-G., and Jang, M.-C.: Enhanced production of oceanic dimethylsulfide resulting from $\mathrm{CO}_{2}$-induced grazing activity in a high $\mathrm{CO}_{2}$ world, Environ. Sci. Technol., 44, 8140-8143, 2010.
Kirkevåg, A., Iversen, T., Seland, Ø., Hoose, C., Kristjánsson, J. E., Struthers, H., Ekman, A. M. L., Ghan, S., Griesfeller, J., Nilsson, E. D., and Schulz, M.: Aerosol-climate interactions in the Norwegian Earth System Model - NorESM1-M, Geosci. Model Dev., 6, 207-244, doi:10.5194/gmd-6-207-2013, 2013.

Kleypas, J. A., Feely, R. A., Fabry, V. J., Langdon, C., and Sabine, C. L., and Robbins, L. L.: Impacts of ocean acidification on coral reefs and other marine calcifiers: a guide for future research, in: Report of a workshop held 18-20 April 2005, St. Petersburg, Vol. 18, p. 88, 2006.

Knopf, D., Alpert, P., Wang, B., and Aller, J.: Stimulation of ice nucleation by marine diatoms, Nat. Geosci., 4, 88-90, 2011.

Kristensen, E., Ahmed, S. I., and Devol, A. H.: Aerobic and anaerobic decomposition of organic matter in marine sediment: Which is fastest?, Limnol. Oceanogr., 40, 1430-1437, 1995.

Laube, J. C., Engel, A., Bönisch, H., Möbius, T., Worton, D. R., Sturges, W. T., Grunow, K., and Schmidt, U.: Contribution of very short-lived organic substances to stratospheric chlorine and bromine in the tropics - a case study, Atmos. Chem. Phys., 8, 7325-7334, doi:10.5194/acp-8-7325-2008, 2008.

Laufkötter, C., Vogt, M., Gruber, N., Aita-Noguchi, M., Aumont, O., Bopp, L., Buitenhuis, E., Doney, S. C., Dunne, J., Hashioka, T., Hauck, J., Hirata, T., John, J., Le Quéré, C., Lima, I. D., Nakano, H., Seferian, R., Totterdell, I., Vichi, M., and Völker, C.: Drivers and uncertainties of future global marine primary production in marine ecosystem models, Biogeosciences, 12, 69556984, doi:10.5194/bg-12-6955-2015, 2015.

Laufkötter, C., Vogt, M., Gruber, N., Aumont, O., Bopp, L., Doney, S. C., Dunne, J. P., Hauck, J., John, J. G., Lima, I. D., Seferian, R., and Völker, C.: Projected decreases in future marine export production: the role of the carbon flux through the upper ocean ecosystem, Biogeosciences, 13, 4023-4047, doi:10.5194/bg-134023-2016, 2016.

Lengaigne, M., Madec, G., Bopp, L., Menkes, C., Aumont, O., and Cadule, P.: Bio-physical feedbacks in the Arctic Ocean using an Earth system model, Bio-physical feedbacks in the Arctic Ocean using an Earth system model, Geophys. Res. Lett., 36, L21602, doi:10.1029/2009GL040145, 2009.

Le Quéré, C.: Reply to Horizons Article "Plankton functional type modelling: running before we can walk" Anderson (2005): I. Abrupt changes in marine ecosystems?, J. Plankton Res., 28, 871-872, 2006.

Le Quéré, C., Harrison, S. P., Prentice, I. C., Buitenhuis, E. T., Aumont, O., Bopp, L., Claustre, H., da Cunha, L. C., Geider, R., Giraud, X., Klaas, C., Kohfeld, K. E., Legendre, L., Manizza, M., Platt, T., Rivkin, R. B., Sathyendranath, S., Uitz, J., Watson, A. J., and Wolf-Gladrow, D.: Ecosystem dynamics based on plankton functional types for global ocean biogeochemistry models, Glob. Change Biol., 11, 1-25, doi:10.1111/j.1365-2486.2005.1004.x, 2005.

Liss, P. and Duce, R.: The sea surface and global change, Cambridge University Press, UK, 2005.

Lohbeck, K., Riebesell, U., and Reusch, T. B. H.: Adaptive evolution of a key phytoplankton species to ocean acidification, Nat. Geosci., 5, 346-351, 2012.

Maier-Reimer, E., Kriest, I., Segschneider, J., and Wetzel, P.: The Hamburg oceanic carbon cycle circulation model HAMOCC5.1 - Technical Description Release 1.1, in: Tech. Rep. 14, Reports 
on Earth System Science, Max Planck Institute for Meteorology, Hamburg, Germany, 2005.

Malin, G., Turner, S., Liss, P., Holligan, P., and Harbour, D.: Dimethylsulphide and dimethylsulphoniopropionate in the Northeast Atlantic during the summer coccolithophore bloom, Deep-Sea Res. Pt. I, 40, 1487-1508, 1993.

Martinez-Rey, J., Bopp, L., Gehlen, M., Tagliabue, A., and Gruber, N.: Projections of oceanic $\mathrm{N}_{2} \mathrm{O}$ emissions in the 21st century using the IPSL Earth system model, Biogeosciences, 12, 41334148, doi:10.5194/bg-12-4133-2015, 2015.

McCoy, D., Burrows, S., Wood, R., Grosvenor, D., Elliott, S., Ma, P., Rasch, P., and Hartmann, D.: Natural aerosols explain seasonal and spatial patterns of Southern Ocean cloud albedo, Science Advances, 1, e1500157, doi:10.1126/sciadv.1500157, 2015.

Meskhidze, N. and Nenes, A.: Phytoplankton and cloudiness in the Southern Ocean, Science, 314, 1419-1423, 2006.

Moore, J., Lindsay, K., Doney, S., Long, M., and Misumi, K.: Marine ecosystem dynamics and biogeochemical cycling in the Community Earth System Model [CESM1 (BGC)]: Comparison of the 1990s with the 2090s under the RCP4. 5 and RCP8. 5 scenarios, J. Climate, 26, 9291-9312, 2013.

Moore, R. M., Webb, M., Tokarczyk, R., and Wever, R.: Bromoperoxidase and iodoperoxidase enzymes and production of halogenated methanes in marine diatom cultures, J. Geophys. Res.Ocean., 101, 20899-20908, 1996.

Myhre, G., Shindell, D., Bréon, F., Collins, W., Fuglestvedt, J., Huang, J., Koch, D., Lamarque, J., Lee, D., Mendoza, B., Nakajima, T., Robock, A., Stephens, G., Takemura, T., and Zhang, H.: Anthropogenic and Natural Radiative Forcing, in: Climate change 2013: the physical science basis. Contribution of Working Group I to the fifth assessment report of the intergovernmental panel on climate change, edited by: Stocker, T., Qin, D., Plattner, G., Tignor, M., Allen, S., Boschung, J., Nauels, A., Xia, Y., Bex, V., and Midgley, P., Cambridge University Press, 2013.

Naqvi, S. W. A., Bange, H. W., Farías, L., Monteiro, P. M. S., Scranton, M. I., and Zhang, J.: Marine hypoxia/anoxia as a source of $\mathrm{CH}_{4}$ and $\mathrm{N}_{2} \mathrm{O}$, Biogeosciences, 7, 2159-2190, doi:10.5194/bg7-2159-2010, 2010.

Nightingale, P., Malin, G., and Liss, P.: Production of chloroform and other low-molecular-weight halocarbons by some species of macroalgae, Limnol. Oceanogr., 40, 680-689, 1995.

O’Neil, J. M., Davis, T. W., Burford, M. A., and Gobler, C. J.: The rise of harmful cyanobacteria blooms: The potential roles of eutrophication and climate change., Harmful Algae, 14, 313-334, 2012.

Palmer, J. and Totterdell, I.: Production and export in a global ocean ecosystem model, Deep-Sea Res. Pt. I, 48, 1169-1198, 2001.

Patara, L., Vichi, M., Masina, S., Fogli, P., and Manzini, E.: Global response to solar radiation absorbed by phytoplankton in a coupled climate model, Clim. Dynam., 39, 1951-1968, 2012.

Piontek, J., Lunau, M., Händel, N., Borchard, C., Wurst, M., and Engel, A.: Acidification increases microbial polysaccharide degradation in the ocean, Biogeosciences, 7, 1615-1624, doi:10.5194/bg-7-1615-2010, 2010.

Pomeroy, L. R. and Deibel, D.: Temperature regulation of bacterial activity during the spring bloom in Newfoundland coastal waters, Science, 233, 359-361, 1986.

Pöschl, U. and Shiraiwa, M.: Multiphase Chemistry at the Atmosphere-Biosphere Interface Influencing Climate and Pub- lic Health in the Anthropocene, Chem. Rev., 115, 4440-4475, 2015.

Quinn, P. K. and Bates, T. S.: The case against climate regulation via oceanic phytoplankton sulphur emissions, Nature, 480, 5156,2011

Rap, A., Scott, C., Spracklen, D., Bellouin, N., Forster, P., Carslaw, K., Schmidt, A., and Mann, G.: Natural aerosol direct and indirect radiative effects, Geophys. Res. Lett., 40, 3297-3301, 2013.

Raven, J. A.: Praeger Review: Effects on marine algae of changed seawater chemistry with increasing atmospheric $\mathrm{CO}_{2}$, in: Biology and Environment: Proceedings of the Royal Irish Academy, Vol. 111B, 1-17, Royal Irish Academy, 2011.

Reisch, C. R., Moran, M. A., and Whitman, W. B.: Bacterial catabolism of dimethylsulfoniopropionate (DMSP), Front. Microbiol., 2, 1-12, 2011.

Rost, B. and Riebesell, U.: Coccolithophores and the biological pump: responses to environmental changes, in: Coccolithophores: from molecular processes to global impact, edited by: Thierstein, R. and Young, J. R., 99-125, Springer, 2004.

Saiz-Lopez, A., Lamarque, J.-F., Kinnison, D. E., Tilmes, S., Ordóñez, C., Orlando, J. J., Conley, A. J., Plane, J. M. C., Mahajan, A. S., Sousa Santos, G., Atlas, E. L., Blake, D. R., Sander, S. P., Schauffler, S., Thompson, A. M., and Brasseur, G.: Estimating the climate significance of halogen-driven ozone loss in the tropical marine troposphere, Atmos. Chem. Phys., 12, 3939-3949, doi:10.5194/acp-12-3939-2012, 2012.

Sarmiento, J. L., Slater, R. D., Dunne, J., Gnanadesikan, A., and Hiscock, M. R.: Efficiency of small scale carbon mitigation by patch iron fertilization, Biogeosciences, 7, 3593-3624, doi:10.5194/bg-7-3593-2010, 2010.

Sathyendranath, S., Gouveia, A. D., Shetye, S. R., Ravindran, P., and Platt, T.: Biological control of surface temperature in the Arabian Sea, Nature, 349, 54-56, 1991.

Schneider, B., Bopp, L., Gehlen, M., Segschneider, J., Frölicher, T. L., Cadule, P., Friedlingstein, P., Doney, S. C., Behrenfeld, M. J., and Joos, F.: Climate-induced interannual variability of marine primary and export production in three global coupled climate carbon cycle models, Biogeosciences, 5, 597-614, doi:10.5194/bg-5-597-2008, 2008.

Segschneider, J. and Bendtsen, J.: Temperature-dependent remineralization in a warming ocean increases surface $\mathrm{pCO}_{2}$ through changes in marine ecosystem composition, Global Biogeochem. Cy., 27, 1944-9224, 2013.

Six, K. D., Kloster, S., Ilyina, T., Archer, S. D., Zhang, K., and Maier-Reimer, E.: Global warming amplified by reduced sulphur fluxes as a result of ocean acidification, Nature Climate Change, 3, 975-978, 2013.

Sonntag, S.: Modeling biological-physical feedback mechanisms in marine systems, $\mathrm{PhD}$ thesis, Universität Hamburg, available at: http://ediss.sub.uni-hamburg.de/volltexte/2013/6427 (last access: 23 January 2017), 2013.

Sonntag, S. and Hense, I.: Phytoplankton behavior affects ocean mixed layer dynamics through biological-physical feedback mechanisms, Geophys. Res. Lett., 38, L15610, doi:10.1029/2011GL048205, 2011.

Steinacher, M., Joos, F., Frölicher, T. L., Plattner, G.-K., and Doney, S. C.: Imminent ocean acidification in the Arctic projected with the NCAR global coupled carbon cycle-climate model, Biogeosciences, 6, 515-533, doi:10.5194/bg-6-515-2009, 2009. 
Stemmler, I., Hense, I., Quack, B., and Maier-Reimer, E.: Methyl iodide production in the open ocean, Biogeosciences, 11, 44594476, doi:10.5194/bg-11-4459-2014, 2014.

Stemmler, I., Hense, I., and Quack, B.: Marine sources of bromoform in the global open ocean - global patterns and emissions, Biogeosciences, 12, 1967-1981, doi:10.5194/bg-12-1967-2015, 2015.

Stramma, L., Johnson, G. C., Sprintall, J., and Mohrholz, V.: Expanding oxygen-minimum zones in the tropical oceans, Science, 320, 655-658, 2008

Sturges, W. T., Oram, D. E., Carpenter, L. J., Penkett, S. A., and Engel, A.: Bromoform as a source of stratospheric bromine, Geophys. Res. Lett., 27, 2081-2084, 2000.

Taucher, J., Bach, L. T., Riebesell, U., and Oschlies, A.: The viscosity effect on marine particle flux: A climate relevant feedback mechanism, Global Biogeochem. Cy., 28, 415-422, 2014.

Tyrrell, T., Holligan, P. M., and Mobley, C. D.: Optical impacts of oceanic coccolithophore blooms, J. Geophys. Res.-Ocean., 104, 3223-3241, 1999.

Valentine, D.: Emerging topics in marine methane biogeochemistry, Annu. Rev. Mar. Sci., 3, 147-171, 2011.

Vichi, M., Pinardi, N., and Masina, S.: A generalized model of pelagic biogeochemistry for the global ocean ecosystem. Part I: Theory, J. Marine Syst., 64, 110-134, 2007.

Vichi, M., Manzini, E., Fogli, P., Alessandri, A., Patara, L., Scoccimarro, E., Masina, S., and Navarra, A.: Global and regional ocean carbon uptake and climate change: sensitivity to a substantial mitigation scenario, Clim. Dynam., 37, 1929-1947, 2011.
Volk, T. and Hoffert, M.: Ocean carbon pumps: Analysis of relative strengths and efficiencies in ocean-driven atmospheric $\mathrm{CO}_{2}$ changes, in: The Carbon Cycle and Atmospheric CO: Natural Variations Archean to Present, edited by: Sundquist, E. T. and Broecker, W. S., 99-110, doi:10.1029/GM032p0099, American Geophysical Union, Washington, D.C., 1985.

Watanabe, S., Hajima, T., Sudo, K., Nagashima, T., Takemura, T., Okajima, H., Nozawa, T., Kawase, H., Abe, M., Yokohata, T., Ise, T., Sato, H., Kato, E., Takata, K., Emori, S., and Kawamiya, M.: MIROC-ESM 2010: model description and basic results of CMIP5-20c3m experiments, Geosci. Model Dev., 4, 845-872, doi:10.5194/gmd-4-845-2011, 2011.

Watson, A. and Lovelock, J.: Biological homeostasis of the global environment: the parable of Daisyworld, Tellus B, 35, 284-289, 1983.

Wilson, T., Ladino, L., Alpert, P., Breckels, M., Brooks, I., Browse, J., Burrows, S., Carslaw, K., Huffman, J., Judd, C., and Kilthau, W.: A marine biogenic source of atmospheric ice-nucleating particles, Nature, 525, 234-238, 2015.

Wu, T., Li, W., Ji, J., Xin, X., Li, L., Wang, Z., Zhang, Y., Li, J., Zhang, F., Wei, M., and Shi, X.: Global carbon budgets simulated by the Beijing Climate Center Climate System Model for the last century, J. Geophys. Res.-Atmos., 118, 4326-4347, 2013.

Zhang, H. and Cao, L.: Simulated effect of calcification feedback on atmospheric $\mathrm{CO}_{2}$ and ocean acidification, Scientific reports, 6, 20284, doi:10.1038/srep20284, 2016. 